e-ISSN: 2615-3076(Online), p-ISSN: 2615-1715(Print)

www.birci-journal.com

emails;birci.journal@gmail.com andbirci.journal.org@gmail.com

\title{
The Correlation between Language Acquisition and Language
} Planning

\author{
Ramlan \\ Jabal Ghafur University (UNIGHA), Aceh, Indonesia \\ Email:ramj.khaju@yahoo.com
}

\begin{abstract}
Language acquisition is a process which can take place at any period of one's life. In the sense of first language acquisition, however, it refers to the acquisition (unconscious learning) of one's native language (or languages in the case of bilinguals) during the first 6 or 7 years of one's life (roughly from birth to the time one starts school).Language acquisition planning has a significant correlation to the language acquisition by the students. Because the students' age in between zero up to five years is the appropriate moment to acquire a certain language.
\end{abstract}

Keywords: language acquisition; language planning; sociolinguistics; society

\section{INTRODUCTION}

Language is a system that consists of the development, acquisition, maintenance and use of complex systems of communication, particularly the human ability to do so; and a language is any specific example of such a system. The scientific study of language is called linguistics. Questions concerning the philosophy of language, such as whether words can represent experience, have been debated at least since Gorgias and Plato in ancient Greece. Thinkers such as Rousseau have argued that language originated from emotions while others like Kant have held that it originated from rational and logical thought. 20th-century philosophers such as Wittgenstein argued that philosophy is really the study of language. Major figures in linguistics include Ferdinand de Saussure and Noam Chomsky. Estimates of the number of human languages in the world vary between 5,000 and 7,000. However, any precise estimate depends on a partly arbitrary distinction between languages and dialects. Natural languages are spoken or signed, but any language can be encodedinto secondary media using auditory, visual, or tactile stimuli- for example, in whistling, signed, or braille. This is because human language is modality-independent. Depending on philosophical 


\section{Budapest International Research and Critics Institute-Journal (BIRCI-Journal) \\ Volume I, February 2018, Page: 20-26 \\ e-ISSN: 2615-3076(Online), p-ISSN: 2615-1715(Print) \\ www.birci-journal.com \\ emails;birci.journal@gmail.com andbirci.journal.org@gmail.com}

perspectives regarding the definition of language and meaning, when used as a general concept, "language" may refer to the cognitive ability to learn and use systems of complex communication, or to describe the set of rules that makes up these systems, or the set of utterances that can be produced from those rules. All languages rely on the process of semiosis to relate signs to particular meanings. Oral, manual and tactile languages contain a phonological system that governs how symbols are used to form sequences known as words or morphemes, and a syntactic system that governs how words and morphemes are combined to form phrases and utterances.

Human language has the properties of productivity and displacement, and relies entirely on social convention and learning. Its complex structure affords a much wider range of expressions than any known system of animal communication. Language is thought to have originated when early hominins started gradually changing their primate communication systems, acquiring the ability to form a theory of other minds and a shared intentionality. This development is sometimes thought to have coincided with an increase in brain volume, and many linguists see the structures of language as having evolved to serve specific communicative and social functions. Language is processed in many different locations in the human brain, but especially in Broca's and Wernicke's areas. Humans acquire language through social interaction in early childhood, and children generally speak fluently by approximately three years old. The use of language is deeply entrenched in human culture. Therefore, in addition to its strictly communicative uses, language also has many social and cultural uses, such as signifying group identity, social stratification, as well as social grooming and entertainment.

Languages evolve and diversify over time, and the history of their evolution can be reconstructed by comparing modern languages to determine which traits their ancestral languages must have had in order for the later developmental stages to occur. A group of languages that descend from a common ancestor is known as a language family. The Indo-European family is the most widely spoken and includes languages as diverse as English, Russian and Hindi; the SinoTibetan family, which includes Mandarin, Bodo and the other Chinese languages, and Tibetan; the Afro-Asiatic family, which includes Arabic, Somali, and Hebrew; the Bantu languages, which include Swahili, and Zulu, and hundreds of other languages spoken throughout Africa; and the Malayo-Polynesian languages, which include Indonesian, Malay, Tagalog, and hundreds of other languages spoken throughout the Pacific. The languages of the Dravidian family that are spoken 


\section{Budapest International Research and Critics Institute-Journal (BIRCI-Journal) \\ Volume I, February 2018, Page: 20-26 \\ e-ISSN: 2615-3076(Online), p-ISSN: 2615-1715(Print) \\ www.birci-journal.com \\ emails;birci.journal@gmail.com andbirci.journal.org@gmail.com}

mostly in Southern India include Tamil and Telugu. Academic consensus holds that between 50\% and $90 \%$ of languages spoken at the beginning of the 21 st century will probably have become extinct by the year 2100 .

Language acquisition is different from acquisition planning, although they seem alike. Language acquisition simply viewed as the effort to acquire the language, whereas acquisition planning refers to the program on how to enable someone to acquire the language.

This research is an attempt exploring the correlation between language acquisition and acquisition planning. It is based on the perspective that language is acquired during the childish period, which is from zero up to five years old. Therefore, this is related to the fact that acquisition planning is directed to the efforts in which someone is able to acquire the language through his or her education.

\section{REVIEW OF LITERATURE}

\subsection{Language Acquisition}

According to (http://en.wikipedia.org/wiki/Language_acquisition), language acquisition is the process by which humans acquire the capacity to perceive, produce and use words to understand and communicate. This capacity involves the picking up of diverse capacities including syntax: is the study of the principles and rules for constructing sentences in natural languages, phonetics: the study of the sounds of human speech, and an extensive vocabulary: all the words that a person knows or uses. It is surprising to believe how human acquire a language. Human language acquisition is an astonishing process (Guasti: 2002).

Menyuk (1971) suggests three theoretical explanations concerning why children acquire a language: 1) Children essentially acquire language because it is there, a part of his environment, and because vocalization is part of his repertoire of behavior; 2) Children acquire language because of the principles of identification; and 3) Capacities for language acquisition are structurally present at birth.

The capacity to acquire and use language is a key aspect that distinguishes humans from other organisms. Language acquisition usually refers to first language acquisition, which studies infants' acquisition of their native language, rather than second language acquisition that deals with 


\section{Budapest International Research and Critics Institute-Journal (BIRCI-Journal) \\ Volume I, February 2018, Page: 20-26 \\ e-ISSN: 2615-3076(Online), p-ISSN: 2615-1715(Print) \\ www.birci-journal.com \\ emails;birci.journal@gmail.com andbirci.journal.org@gmail.com}

acquisition in both children and adults of additional languages. Most children embark on the encoding process by starting to recognize some words which they encounter frequently on the basis of silent features (Garton and Pratt: 2000). In detailed Clark (2003) states some stages of language acquisition as follows:

1) Infancy. It is the time when a child is a baby or very young starts at zero to seven months

2) Babbling. It is the sounds a baby makes before beginning to say actual words starts at seven to ten months.

3) First recognizable word. A child does this stage at the age twelve months.

4) First word combination. On this stage a child can combine a word and gestures to express what he intends to.

5) Adultlike utterances. This stage occurs when a child is six years old

From the stages above, it is acceptable to state that the process of language acquisition occurs between zero to five old of age (Clark; 2003). However, researchers have characterized the problem of language acquisition as follows (Baker and McCarthy 1981):

1) Children come to have very rich linguistic knowledge that encompasses a potentially in finite number of sentences, although they hear a finite number of sentences.

2) The data that children draw upon consist of positive evidence (sentences that are acceptable in the language they are exposed to).

3) Children are not told which sentences are ill formed or which interpretations sentences cannot have in their language, but eventually they attain this knowledge; all mature speakers can judge whether a sentence is acceptable or not (under a given interpretation).

4) Although children make "errors," they do not make certain errors that would be expected if they generalized from the linguistic input.

Moreover, Clark (2003) classifies three critical problems in acquiring a language: 1) segmentation- how to go about identifying units of phrases, words, morphemes, and sounds segments in the speech stream; 2) invariance- how to identify the different sounds pronounced by the same speakers in a different occasions; and 3) language- how to set of sounds (phonetic segment) relevant to the language he acquires.

A major concern in understanding language acquisition is how these capacities is picked up by infants from what appears to be very little input. A range of theories of has been created in order 


\section{Budapest International Research and Critics Institute-Journal (BIRCI-Journal) \\ Volume I, February 2018, Page: 20-26 \\ e-ISSN: 2615-3076(Online), p-ISSN: 2615-1715(Print) \\ www.birci-journal.com \\ emails;birci.journal@gmail.com andbirci.journal.org@gmail.com \\ to explain this apparent problem including innatism in which a child is born prepared in some}

manner with these capacities, or whether these are learned.

\subsection{Acquisition Planning}

Acquisition planning is a type of language planning in which a national, state or local government system aims to influence aspects of language, such as language status, distribution and literacy through education. Acquisition planning can also be used by non-governmental organizations, but it is more commonly associated with government planning. On the other word, acquisition planning is integrated into a larger language planning process in which the statuses of languages are evaluated, corpuses are revised and the changes are finally introduced to society on a national, state or local level through education systems, ranging from primary schools to universities.

This process of change can entail a variety of modifications, such as an alteration in student textbook formatting, a change in methods of teaching an official language or the development of a bilingual language program, only to name a few. From this perspective, it can be stated that acquisition planning is much more concerned with the modification: the act or process of changing something in order to improve it or make it more acceptable or a change that is made; textbook formatting: the general arrangement, plan, design, and content of textbook; and method of teaching official language: a particular way of teaching official language to the students.

For example, if a government decides to raise the status level of a certain language or change its level of prestige, it can establish a law that requires teachers to teach only in this language or that textbooks are written using only this language's script. This, in turn, would support the elevation of the language's status or could increase its prestige. In this way, acquisition planning is often used to promote language revitalization, which can change a language's status or reverse a language shift, or to promote linguistic purism. In a case where a government revises a corpus, new dictionaries and educational materials will need to be revised in schools in order to maintain effective language acquisition.

The education ministry or education sector of government is typically in charge of making national language acquisition decisions based on state and local evaluation reports. The responsibilities of education sectors vary by country; Robert B. Kaplan and Richard B. Baldauf describe the sectors' six principal goals:

1. To decide what languages should be taught within the curriculum. 


\section{Budapest International Research and Critics Institute-Journal (BIRCI-Journal) \\ Volume I, February 2018, Page: 20-26 \\ e-ISSN: 2615-3076(Online), p-ISSN: 2615-1715(Print) \\ www.birci-journal.com \\ emails;birci.journal@gmail.com andbirci.journal.org@gmail.com}

2. To determine the amount and quality of teacher training.

3. To involve local communities.

4. To determine what materials will be used and how they will be incorporated into syllabi.

5. To establish a local and state assessment system to monitor progress.

6. To determine financial costs.

\section{DISCUSSION}

Maria (2002) says that for children, acquiring a language is an effortless achievement that occurs: without explicit teaching, on the basis of positive evidence (i.e., what they hear), under varying circumstances, and in a limited amount of time, in identical ways across different languages. By around age ten to twelve, they have mastered many complex constructions, a good deal more vocabulary, and many uses of language (Clark: 2003)

Ferguson (2006) Education is probably the most crucial, sometimes indeed bearing the entire burden of LP implementation. The reasons are straightforward: 1) education in most countries is largely funded and thus controlled by the state; 2) Schools are one of the key agencies of socialization; 3) school pupils are a captive audience, and the curriculum affords the state unequaled opportunity to shape the attitudes and behaviors of the next generation.

Ferguson (2006) If language education very often functions as an instrument for the attainment of wider status planning goals (e.g. the disseminations of a national standard language), it may also be a focus of language policy in its own right, one sufficiently distinct to merit a separate label.

\section{DISCUSSION}

Based on the correlation mentioned above, therefore, it can be concluded that language planning, particularly acquisition planning has a significant correlation to the language acquisition by 

to acquire a certain language.

\section{REFERENCES}

Baker, C. L., and J. J. McCarthy, eds. (1981) The Logical Problem of language Acquisition. Cambridge, Mass. : MIT Press

Clark, Eve V. (2003) First language Acquisition. London: Cambridge University Press

Ferguson, Gibson (2006) Language Planning and Education. Great Britain: Edinburgh University Press Ltd

Menyuk, Paula (1971) The Acquisition and Development of Language. New York: Prentice-Hall, Inc.

Garton, Alison and Pratt, Chris (2000) Learning to be Literate: the Development of Spoken and Written Language. Malden: Blackwell Publisher Inc.

Guasti, Maria Teresa (2002) Language Acquisition: the Growth of Grammar Cambridge, Mass. : MIT Press

http://en.wikipedia.org/wiki/Language_acquisition, accessed on March 22, 2010

http://en.wikipedia.org/wiki/Language_planning, accessed on March 22, 2010 